\title{
MANAJEMEN PENGEMBANGAN KOMPETENSI PROFESIONAL GURU
}

Panji Alam Muhamad Ikbal

Madrasah Aliyah Negeri 1 Garut

JI. A. Yani, Koropeak, Suci, Garut Kota, Kabupaten Garut, Jawa Barat 44182

Email: alpanji15@gmail.com

\section{ABSTRAK}

Tujuan penelitian ini untuk mengetahui manajemen pengembangan kompetensi profesional guru di Madrasah Aliyah Negeri 1 Garut. Penelitian ini dilaksanakan melalui pendekatan kualitatif dengan menggunakan metode deskriptif. Teknik pengumpulan data dengan wawancara, observasi, dan studi dokumentasi. Sumber data adalah kepala madrasah, wakil kepala sekolah, dan guru. Setelah dilakukan penelitian terlihat bahwa kebijakan, perencanaan, pelaksanaan, faktor pendukung dan penghambat, dan dampak pengembangan kompetensi profesional guru yang dilaksanakan berjalan sesuai dengan tujuan dan terencana dengan melibatkan berbagai pihak, terbentuknya team work. Kebijakan pengembangan kompetensi profesional guru berasal dari pemerintah melalui PKG, dan sertifikasi pendidik, juga kebijakan kepala madrasah dengan memberikan supervisi dan memfasilitasi guru. Perencanaan pengembangan kompetensi profesional guru dengan membuat pemetaan terhadap guru sesuai kebutuhan pengembangannya, merencanakan program sesuai kebutuhan. Pelaksanaan pengembangan kmpetensi profesional guru melalui pentaranpenataran, pelatihan, supervisi, dll, Faktor pendukung ialah pemerintah menyediakan program memberikan tunjangan sertifikasi profesi, kepala madrasah memberikan supervisi dan program pengembangan. Faktor penghambat ialah: dalam pelaksanaannya terkadang terbentur dengan jadwal kegiatan guru dan keterbatasan anggaran. Dampaknya ialah bahwa guru mampu menjalankan tugasnya sebagai pendidik dengan profesional. Sisiwa dapat mengaplikasikan teori yang dipelajarinya, serta prestasi siswa akan meningkat. Madrasah memiliki strategi dan metode pembelajaran yang bervariasi, berbagai program yang mengembangkan akademi.

Kata kunci : Pengembangan, kompetensi, profesional.

\section{ABSTRACT}

The purpose of this study to determine the management of professional competency development of teachers in Madrasah Aliyah Negeri 1 Garut. This research is conducted through qualitative approach by using descriptive method. Technique of collecting data by interview, observation, and study of documentation. Data sources are headmaster, deputy headmaster, and teacher. After doing research, it is seen that the policy, planning, implementation, supporting and inhibiting factors, and the impact of teacher 
professional competence development are carried out in accordance with the goals and planned by involving various parties, the formation of team work. The teacher professional competence development policy comes from the government through PKG, and certification of educators, as well as the policy of the head of the madrasah by providing supervision and facilitation of teachers. Planning the development of professional competence of teachers by making mapping of teachers according to their development needs, plan the program as needed. Implementation of the development of professional teachers through professional training, training, supervision, etc. The supporting factor is that the government provides programs to provide professional certification allowances, heads of madrasahs providing supervision and development programs. Inhibiting factors are: in practice sometimes collide with teacher activity schedule and budget constraints. The impact is that teachers are able to perform their duties as educators with professionals. Sisiwa can apply the theory he / she learns, and student achievement will increase. Madrasahs have varied strategies and learning methods, various programs that develop the academy.

Keywords: Development, competence, professional.

\section{PENDAHULUAN}

Guru adalah sebuah profesi. Kompetensi guru yang profesional, sebagaimana tercantum dalam pasal 4 tersebut, keenam aspek itu, perlu mendapat cermata dengan seksama, sehingga bisa dijelaskan dengan baik mengenai kualitas dan profesi guru itu sendiri dan untuk selanjutnya, dengan kriteria atau indikator itulah, kemudian posisi guru saat ini dianggap dan diposisikan sebagai sebuah profesi. Dalam kaitan ini, sertifikasi profesi hanya merupakan tanda atau simbol pengakuan mengenai kemampuan profesional guru, kualitas seseorang disebut profesional. Profesionalisme itu merupakan kecendrungan sikap, mental atau tindakan anggota dalam menjalankan tugas profesinya. Oleh karena itu profesionalisme dapat diartikan pula sebagai komitmen seseorang atau anggota suatu profesi untuk menjalankan tugas dan fungsinya. Tingkat kualitas profesionalisme itulah yang di kemudian disebut profesionalitas. Sedangkan proses peningkatan kualitas keguruan, atau dengan istilah lain sebagai profesionalisasi (Momon Sudarman, 2013, h. 3-5)

Pendidik profesional yang dimaksud adalah pendidik yang berkualitas, berkompetensi, dan pendidik yang dikehendaki untuk mendatagkan prestasi belajar serta mampu mempengaruhi proses belajaar mengajar siswa yang nantinya akan menghasilkan prestasi belajar siswa yang baik (Hamalik,. 2006, h. 36).

Guru profesional sesuai yang disyaratkan oleh Undang-Undang RI Nomor 20 Tahun 2003 tentang Sistem Pendidikan Nasional Pasal 40 ayat 2 yaitu (a) bahwa pendidik dan tenaga kependidikan berkewajiban menciptakan suasana pendidikan yang bermakna, menyenangkan, kreatif, dinamis dan dialogis, kemudian (b) mempunyai komitmen secara profesional untuk meningkatkan mutu pendidikan". Dalam hal ini pendidik diharapkan: pertama, memiliki dasar ilmu yang kuat sebagai pengetahuan terhadap masyarakat teknologi dan masyarakat ilmu pengetahuan di abad 21. Kedua, memiliki kiat- 
kiat profesi berdasarkan riset dan praktik pendidikan yaitu ilmu pendidikan sebagai ilmu praktis bukan hanya merupakan konsep-konsep belaka.

Hamzah B. Uno (2007, h. 17) menyatakan "apabila seseorang ingin menjadi guru yang profesional maka sudah seharusnya dapat selalu meningkatkan wawasan pengetahuan akademis dan praktis melalui jalur pendidikan berjenjang ataupun upgrading dan/atau pelatihan yang bersifat in service training dengan rekan-rekan sejawatnya".

\section{KAJIAN TEORI}

Menurut Husaini Usman kata "manajemen" akar bahasanya ternyata berasal dari bahasa Latin, yaitu dari kata manus yang berarti tangan, dan agree yang berarti melakukan. Kata-kata sebagaimana yang telah diuraikan, jika digabung menjadi kata kerja "manager" yang artinya menangani. Kata managere ini jika diterjemahkan kedalam bahasa Inggris dalam bentuk kata kerja to manage, dengan kata benda management, dan manager untuk orang yang melakukan kegiatan manajemen. Akhirnya management diterjemahkan ke dalam bahasa Indonesia menjadi manajemen atau pengelolaan (Agus Wibowo, 2013, h. 29).

G. R. Terry mendefinisikan manajemen sebagai; "management is a distinc process consist of planing, organizing, actuating, and controlling, performed to determine and accomplish state objectives by the use of human being and other resourches". Dari definisi yang disampaikan Terry tersebut, dapat diketahui bahwa manajemen merupakan suatu proses yang khas; yang terdiri atas perencanaan, pengorganisasian, penggerakan dan pengontrolan, guna mencapai tujuan yang telah ditetapkan dengan menggunakan sumber daya manusia dan sumber daya lain (Agus Wibowo, 2013:29).

Henry mendefinisikan manajemen sebagai proses pendayagunaan bahan baku dan sumber daya manusia, untuk mencapai tujuan yang ditetapkan. Proses tersebut melibatkan organisasi, arahan, koordinasi, dan evaluasi orang-orang guna mencapai tujuan. dari definisi tersebut diketahui esensi manajemen menurut Henry adalah aktivitas bekerja melalui orang lain, untuk meraih berbagai hasil. Melalui manajemen, dilakukan proses pengintegrasian berbagai sumberdaya dan tugas, untuk mencapai berbagai tujuan organisasi (Agus Wibowo, 2013, h. 31).

Pengembangan adalah suatu usaha untuk meningkatkan kemampuan teknis, teoretis, konseptual, dan moral karyawan sesuai dengan kebutuhan pekerjaan/jabatan melalui pendidikan dan latihan. Pengembangan karyawan (baru/lama) perlu dilakukan secara terencana dan berkesinambungan. Agar pengembangan ini dapat dilaksanakan dengan baik harus lebih dahulu ditetapkan suatu program pengembangan karyawan (Hasibuan, 1995:75-76). Mengacu pada penjelasan diatas pendidik harus senantiasa mengembangkan kemampuannya melalui program pendidikan dan latihan yang telah direncanakan pemerintah melalui lembaga madrasah secara berkesinambungan sesuai dengan tuntutan pendidikan masa kini.

Proporsi antara pengetahuan sikap, dan keterampilan sangat tergantung pada jenis pekerajaan. Kompetensi adalah kemampuan melaksanakan sesuatu yang diperoleh melalui pendidikan dan latihan. Dengan demikian istilah kompetensi sangat kontekstual dan tidak universal untuk semua jenis 
pekerjaan. Setiap jenis pekerjaan memerlukan porsi yang berbeda antara pengetahuan, sikap dan keterampilannya. Pekerjaan pekerjaan berkerah putih, pengetahuan lebih besar porsinya dari pada sikap juga keterampilan, dan pekerjaan berkerah biru memerlukan porsi keterampilan fisik lebih besar dari pada pengetahuan dan sikap (Syaiful Sagala, 2011, h. 29).

Profesi guru sebagai pelayan peseta didik berkaitan dengan ilmu pengetahuan, tentu harus mempunyai daya fikir yang cukup dan mampu berfikir sistematis. Maka guru profesional bukanlah hanya untuk satu kompetensi saja yaitu kompetensi profesional, tetapi guru profesional semestinya meliputi semua kompetensi. Sebagaimana diamanatkan UU 14/2005 dan PP 19/2005 agar guru dan dosen memahami, menguasai dan terampil dalam menggunakan sumber-sumber belajar baru dan menguasai keempat kompetensi yaitu, kompetensi paedagogis, kompetensi kepribadian, kompetensi profesional, dan kompetensi sosial sebagai bagian dari kemampuan profesional guru (Syaiful Sagala, 2011, h. 30).

Menurut Suparlan dalam bukunya yang berjudul Menjadi Guru Efektif, mengungkapkan hal yang berbeda tentang pengertian guru. Menurut Suparlan (2008, h. 12), guru dapat diartikan sebagai orang yang tugasnya terkait dengan upaya mencerdaskan kehidupan bangsa dalam semua aspeknya, baik spiritual dan emosional, intelektual, fisikal, maupun aspek lainnya. Namun, Suparlan (2008, h. 13) juga menambahkan bahwa secara legal formal, guru adalah seseorang yang memperoleh surat keputusan (SK), baik dari pemerintah maupun pihak swasta untuk mengajar.

kompetensi profesional guru yang merupakan seperangkat pengetahuan, keterampilan, dan perilaku yang harus dimiliki, dihayati, dan dikuasai oleh guru dalam melaksanakan tugas profesionalnya (Uus Ruswandi dan Badrudin, 2010, h. 38).

Kompetensi profesionalisme guru meliputi:

1. Menguasai materi, struktur, konsep dan pola fikir keilmuan yang mendukung mata pelajaran yang diampu.

2. Menguasai standar kompetensi dan kompetensi dasar mata pelajaran/atau bidang pengembangan yang diampu.

3. Mengembangkan materi pembelajaran yang diampu secara efektif.

4. Mengembangkan keprofesionalan secara berkelanjutan dengan melakukan tindakan reflektif.

5. Memanfaatkan TIK untuk berkomunikasi dan mengembangkan diri. (Uus Ruswandi dan Badrudin, 2010, h. 38).

Kegiatan pembinaan dan pengembangan guru menuju derajat profesional ideal, termasuk dalam kerangka mengelola kelas untuk pembelajaran yang efektif, dilakukan atas dasar prakarsa pemerintah, pemerintah daerah, penyelenggara satuan pendidikan, asosiasi guru, guru secara pribadi dan lain-lain. Secara umum kegiatan dimaksud untuk merangsang, memelihara, dan meningkatkan kompetensi guru dalam memecahkan masalah-masalah pendidikan dan pembelajaran yang berdampak pada peningkatan mutu hasil belajar siswa. Pembinaan dan pengembangan profesional guru atas prakarsa institusi, seperti pendidikan dan pelatihan, workshop, magang, studi banding dan lain-lain adalah penting. Namun, yang tidak kalah pentingnya adalah prakarsa personal guru untuk menjalani proses 
profesionalisasi. Kegiatan PPPG idealnya dilaksanakan secara sistematis dengan menempuh tahapan-tahapan tertentu, seperti analisis kebutuhan, perumusan tujuan dan sasaran, mendesain program, implementasi dan delivery program, dan evaluasi program ini berarti bahwa kegiatan pembinaan dan pengembangan kemampuan profesional guru secara berkelanjutan harus dilaksanakan atas dasar pelaksanaan, dan evaluasi yang sistematis (Sudarwan Danim, 2010, h. 20).

\section{METODE PENELITIAN}

Metode penelitian yang digunakan dalam penelitian ini adalah metode deskriptif dengan pendekatan kualitatif, metode ini digunakan untuk pemecahan masalah yang diteliti ditujukan untuk menggali data dan informasi yang berkaitan dengan manajemen pengembangan kompetensi profesional guru.

Penelitian yang dilakukan di Madrasah Aliyah Negeri 1 Garut, penempatan tempat penelitian ini didasarkan pada penelitian studi pendahuluan yang dilaksanakan peneliti. Adapun yang menjadi sumber data dalam penelitian ini adalah Kepala Madrasah sebagai informan awal dipilih secara purposive, objek penelitian yang menguasai permasalah yang diteliti yaitu (key informan), kemudian Staf, dn guru. Sumber data yang diperlukan dalam penelitian ini dapat dikategorikan ke dalam dua kelompok, yaitu data primer dan data sekunder. Teknik pengumpulan data meliputi 1) wawancara, 2) observasi, 3) dan dokumentasi.

Analisis data dilakukan dengan dengan kategorisasi data penafsiran data. Adapun uji absah data dilakukan dengan perpanjangan keikut sertaan, ketekunan pengamatan, analisis kecakapan negatif, kecukupan referensi, uraian rinci dan auditing (Moleong, 2016, h. 137)

\section{HASIL DAN PEMBAHASAN \\ Kebijakan Pengembangan Kompetensi Profesional Guru}

Kebijakan pengembangan kompetensi profesional guru di MAN 1 Garut dengan memerhatikan Undang-Undang RI nomor 14 tahun 2005 tentang Guru dan Dosen, pada pasal 4 dinyatakan bahwa "profesi pekerja profesional adalah pekerjaan atau kegiatan yang dilakukan oleh seseorang dan menjadi sumber penghasilan kehidupan yang memerlukan keahlian, kemahiran, atau kecakapan yang memenuhi standar mutu atau norma tertentu serta memerlukan pendidikan profesi".

Selain dari pada itu Pemerintah dalam rangka meningkatkan mutu pendidikan nasional melalui peningkatan komponen mutu guru, telah meluncurkan program yaitu Sertifikasi guru, proses pemberian sertifikat kepada para guru yang telah memenuhi standar professional guru. Pemerintah berharap dari program sertifikasi ini profesionalisme guru akan meningkat sehingga pada akhirnya, mutu pendidikan akan meningkat pula.

Kebijakan yang diberikan kepala madrasah Dalam upaya pengembangan kompetensi profesional guru, yaitu memberikan supervisi kepada guru untuk mengetahui sejauh mana guru mampu melaksanakan pembelajaran secara berkala, maka dapat dilakukan melalui kegiatan kunjungan kelas untuk mengamati proses pembelajaran secara langsung, terutama dalam pemilihan dan penggunaan metode, media yang digunakan 
dan keterlibatan siswa dalam proses pembelajaran. Kemudian mengadakan kegiatan penataran yang berhubungan dengan pelaksanaan tugas guru terutama sekali dalam pelaksanaan proses belajar mengajar, sehingga setelah mengikuti penataran tersebut diharapkan mampu memiliki pengetahuan, keterampilan, dan pengalaman baru tentang berbagai permasalahan pelaksanaan tugas guru.

\section{Perencanaan Pengembangan Kompetensi Profesional Guru}

Perencanaan Pengembangan Kompetensi Profesional guru di Madrasah Aliyah Negeri 1 Garut yaitu memilih program pengembangan kompetensi profesional guru sesuai dengan kebutuhan, bisa menggantikan program yang sudah terlaksana atau menambah program yang lain. Program tersebut diantaranya: penataran-penataran, workshop, Pelatihan, MGMP, dan lain-lain. Merencanakan alokasi anggaran biaya khususnya dalam pengembangan kompetensi guru setiap tahunnya dengan menggunakan prinsip efektif dan efesien, karena anggaran program tersebut sangat terbatas.

Mengadakan pemetaan Bagi guru yang belum pernah mengikuti pengembangan dan yang sangat memerlukan pengembangan kompetensi profesional guru akan dilakukan pemetaan dan selanjutnya dari hasil pemetaan itu disosialisasikan kepada guru melalui rapat pertemuan sosialisasi pengembangan kompetensi profesional guru. Melalui pertemuan ini diharapkan kepada semua guru selalu mempersiapkan diri terhadap pelaksanaan pengembangan kompetensi profesional guru yang akan dilaksanakan melalui internal madrasah dan eksternal madrasah bekerja sama dengan instansi terkait, melalui internal madrasah kegiatan yang akan dilaksanakan yaitu Supervisi oleh kepala Madrasah dan dibantu oleh petugas lain yang ditunjuk oleh kepala Madrasah. Melalui eksternal Madrasah yang akan dilaksanakan oleh instansi terkait seperti Dinas Pendidikan Nasional dan Kebudayaan Kabupaten/Kota maupun Dinas Pendidikan Nasional dan Kebudayaan Provinsi.

\section{Pelaksanaan Pengembangan Kompetensi Profesional Guru}

Pelaksanaan. pelaksanaan pengembangan Kompetensi Profesional guru di MAN 1 Garut yang dilaksanakan yaitu:

\section{Tabel 1}

Guru yang Telah Mengikuti Kegiatan Pengembangan Kompetensi/Profesionalisme

\begin{tabular}{|c|l|c|c|c|c|}
\hline \multirow{2}{*}{ No. } & \multicolumn{1}{|c|}{$\begin{array}{c}\text { Jenis Pengembangan } \\
\text { Kompetensi }\end{array}$} & \multicolumn{4}{|c|}{ Jumlah Guru } \\
\cline { 3 - 6 } & \multicolumn{2}{|c|}{$\begin{array}{c}\text { Laki-laki } \\
\text { 1. Jumlah }\end{array}$} & Perempuan & Jumlah \\
\hline 3. & Penataran KBK/KTSP & 28 & 28 & 26 & 26 \\
\hline & $\begin{array}{l}\text { Penataran Metode } \\
\text { Pembelajaran (termasuk } \\
\text { CTL) }\end{array}$ & & & & \\
\hline
\end{tabular}




\begin{tabular}{|c|l|c|c|c|c|}
\hline \multirow{2}{*}{ No. } & \multicolumn{1}{|c|}{$\begin{array}{c}\text { Jenis Pengembangan } \\
\text { Kompetensi }\end{array}$} & \multicolumn{4}{|c|}{ Jumlah Guru } \\
\cline { 3 - 6 } & \multicolumn{2}{|c|}{} & \multicolumn{4}{|c|}{ Laki-laki } & Jumlah & Perempuan & Jumlah \\
\hline 4. & Penataran PTK & 2 & 2 & 2 & 2 \\
\hline 5. & $\begin{array}{l}\text { Penataran Karya Tulis } \\
\text { Ilmiah }\end{array}$ & 2 & 2 & 2 & 2 \\
\hline 6. & $\begin{array}{l}\text { Sertifikasi } \\
\text { Profesi/Kompetensi }\end{array}$ & 24 & 24 & 22 & 22 \\
\hline 7. & Penataran PTBK & & & & \\
\hline 8. & $\begin{array}{l}\text { Penataran lainnya: } \\
\text {-........... }\end{array}$ & & & & \\
\hline
\end{tabular}

Selain dari itu, program lain yang dilaksanakan dalam pengembangan kompetensi profesional guru diantaranya :

1. Program peningkatan kualifikasi pendidikan guru

2. Program penyetaraan dan sertifikasi

3. Program supervisi pendidikan

4. Program pemberdayaan MGMP

5. Program pengembangan yang dilakukan oleh guru sendiri

Pada waktu pelaksanaanya yaitu semester ganjil dimulai pada bulan Mei dan Juni, baik yang dilaksanakan oleh internal maupun eksternal madrasah, untuk semester genap pelaksanaan pengembangan Kompetensi Profesional guru di internal madrasah MAN 1 Garut yaitu dimulai pada bulan Nopember dan Desember berupa Supervisi pelaksanaan mengajar oleh Kepala Madrasah adapun yang dilaksanakan oleh eksternal madrasah yaitu pada bulan Juli sampai dengan bulan Nopember tahun belajar berjalan dengan kegiatan Workshop, Pelatihan, MGMP, dan lain-lain. Namun itu sangat jarang kegiatan seperti workshop atau semacam pelatihan terselenggara karena adanya keterbatasan dana yang harus di keluarkan untuk mengadakan program itu.

\section{Faktor Pendukung Dan Penghambat Pengembangan Kompetensi Profesional Guru}

Faktor pendukung meliputi: Pemerintah, memberikan stimulus tunjangan profesi melalui Peraturan Pemerintah No 41 Tahun 2009 tentang tunjangan profesi guru dan dosen. Usaha ini untuk meningkatkan profesional guru dan peningkatan kesejahteraan guru, dalam hal ini gaji merupakan salah satu sumber kepuasan kerja. Madarasah, memberikan fasilitas pendukung program pengembangan kompetensi profesional guru dan kepala madrasah memberikan supervisi kepada guru juga memberikan kesempatan guru mengikuti kegiatan program pengembangan. Pengawas, memberikan motivasi 
bagi guru dalam meningkatkan kompetensinya melalui program pengembangan yang dilaksanakan. Motivasi dari guru sendiri yang selalu ingin terus memperbaik kinerjanya dan meningkatkan kompetensi profesionalnya.

Faktor penghambat: Pengembangan kompetensi profesional guru pelaksanaanya terkadang berbenturan dengan jadwal kegiatan guru atau dengan kegiatan yang ada di sekolah. Control yang belum optimal dan sistematis dari kepala madrasah, sehingga belum terukur secara valid yang dapat ditunjukan dengan data. Kurangnya kesempatan untuk mengembangkan profesi secara berkelanjutan. Banyak guru yang terjebak pada rutinitas. Semakin cepatnya perkembangan tehnologi sehingga guru lebih proaktif dalam mengikuti perkembangan.

\section{Dampak Pengembangan Kompetensi Profesional Guru}

Bagi guru: Setelah melakukan pengembangan kompetensi profesionalnya makan guru akan mengalami peningkatan baik terhadap fisik, keperibadian, kelimuan, pengetahuan dan keterampilannya. Guru mengambil peran penting dalam upaya mencerdaskan peserta didik. Menjadi guru yang profesional dan berkarakter yang mampu menyadari ,menyikapi dan menampilkan diri sebagai seorang guru yang berkarakter yang siap maju dibarisan paling depan memberikan contoh dan teladan tentang sosok manusia yang utuh. Guru senantiasa selalu mengembangkan keprofesionalannya terbukti dengan sikap, kedisiplinan, cara mengajar, menggunakan bahan ajar, mengikuti perkembangan zaman dan juga mereka sendiri berupaya mengembangkan dirinya.

Bagi peserta didik: Peserta didik akan menyenangi proses pembelajaran dan memahami arti penting belajar bagi masa depannya. Pengentahuan yang diproleh peserta didik semakin luas dan wawasan keilmuannya meningkat. Peserta didik lebih mudah menguasai materi pembelajaran, dan metode pembelajaran yang diberikan oleh guru. Motivasi belajarnya meningkat, sehingga memberikan prestasi terbaiknya.

Bagi lembaga: Madarasah menjadi institusi yang efektif, baik ditinjau dari pencapaian tujuan maupun proses dan pendayagunaan sumber daya. Memiliki kurikulum dengan landasan yang kuat, strategi dan metode pembelajaran yang bervariasi, berbagai program yang mengembangkan akademik, bakat, minat dan kreativitas siswa. Mempunyai tujuan dan standar kompetensi yang tinggi.

Menurut Peraturan Pemerintah (PP) No. 74 Tahun 2008 tentang Guru, Bab 1 Pasal 1, bahwa guru adalah pendidik profesional dengan tugas utama mendidik, mengajar, membimbing, mengarahkan, melatih, menilai, dan mengevaluasi peserta didik pada pendidikan anak usia dini jalur pendidikan formal, pendidikan dasar, dan pendidikan menengah.

Semua guru perlu mendapatkan pembinaan terutama sekali guru yang belum menguasai kompetensinya, guru yang belum bisa mengembangkan potensi yang dimiliki, guru yang kurang termotivasi, dan guru yang belum konsisten dalam melaksanakan tugasnya. Menurut Glickman (1981) dalam Arni Muhammad, dkk (2000, h. 6), menyatakan bahwa supervisi adalah serangkaian kegiatan membantu guru mengembangkan kemampuannya mengelola proses belajar mengajar demi pencapaian tujuan pengajaran. 
Supervisi pendidikan dapat dilakukan dengan teknik-teknik sebagai berikut: Teknik individual ( individual technique), yang terdiri dari; kunjungan kelas, observasi kelas, percakapan pribadi, saling mengunjungi kelas dan menilai diri sendiri. Teknik kelompok (group technique), yang terdiri dari; pertemuan orientasi bagi guru baru, rapat guru, studi antar kelompok guru, diskusi, seminar, diskusi panel, buletin supervisi, demonstrasi mengajar, dsb.

Dalam upaya mengembangkan profesi dan kompetensi guru dalam rangka pelaksanaan tugas dan tanggung jawabnya secara profesional, dapat dilakukan melalui beberapa strategi atau model. Pengembangan tenaga kependidikan (guru) "dapat dilakukan dengan cara on the job training dan in service training" (Mulyasa, 2004, h. 154).

Implementasi kemampuan profesional guru mutlak diperlukan sejalan diberlakukannya otonomi daerah, khsususnya bidang pendidikan Kemampuan profesional guru akan terwujud apabila guru memiliki kesadaran dan komitmen yang tinggi dalam mengelola interaksi belajar-mengajar pada tataran mikro, dan memiliki kontribusi terhadap upaya peningkatan mutu pendidikan pada tataran makro.

Program pendidikan baru yang inovatif diberlakukan oleh pemerintah dalam waktu paling tidak lima tahun terakhir ini, seperti broad based education, life skills, manajemen pendidikan berbasis sekolah, contextual teachinglearning $(C T L)$, evaluasi belajar model portofolio, dan yang terakhir Kurikulum Berbasis Kompetensi KBK). Semua itu kurang atau bahkan tidak mengikutsertakan guru sebagai variabel penting dalam pelaksanaan programprogram itu, padahal semua program baru itu bertujuan meningkatkan kualitas pendidikan di negeri ini. Lantas, bagaimana peran guru kita dalam pembaharuan dan inovasi pendidikan itu? Inilah persoalannya. Dengan banyaknya program baru itu, semestinya para guru didorong untuk memiliki profesionalisme yang lebih tinggi. Upaya peningkatan kualitas guru, seharusnya juga diikuti dengan kesejahteraan yang lebih memadai, tetapi kenyataan tidaklah seperti itu dan banyaknya program baru itu justru menambah beban kerja guru.

Rendahnya kualitas tenaga pendidik, merupakan masalah pokok yang dihadapi pendidikan di Indonesia. Katakan saja sebagai contoh, motivasi menjadi tenaga pendidik (guru) di kebanyakan sekolah-sekolah Islam selama ini dikarenakan dan hanya dilandasi oleh faktor pengabdian dan keikhlasan, sedangkan dari sisi kemampuan, kecakapan dan disiplin ilmu dikatakan masih rendah.

Pendidik profesional yang dimaksud adalah pendidik yang berkualitas, berkompetensi, dan pendidik yang dikehendaki untuk mendatangkan prestasi belajar serta mampu mempengaruhi proses belajar mengajar siswa yang nantinya akan menghasilkan prestasi belajar siswa yang baik (Hamalik,. 2006:36).

Keberhasilan guru dapat ditinjau dari dua segi proses dan dari segi hasil. Dari segi proses, guru berhasil bila mamppu melibatkan sebagian besar peserta didik secara aktif baik fisik, mental maupun sosial dalam proses pembelajaran, juga dari semangat mengajarnya serta adanya rasa percaya diri. Sedangkan dari segi hasil, guru berhasil bila pembelajaran yang diberikannya mampu mengubah perilaku pada sebagian besar peserta didik ke arah yang lebih baik. 
Sebaliknya dari sisi siswa, belajar akan berhasil bila memenuhi dua persyaratan: (1) belajar merupakan sebuah kebutuhan siswa, dan (2) ada kesiapan untuk belajar, yakni kesiapan memperoleh pengalaman-pengalaman baru baik pengetahuan maupun keterampilan.

\section{KESIMPULAN}

Kebijakan pengembangan pengembangan kompetensi profesional guru di MAN 1 garut berpedoman pada Undang-Undang RI nomor 14 tahun 2005 tentang Guru dan Dosen, bahwa "profesi pekerja profesional adalah pekerjaan atau kegiatan yang dilakukan oleh seseorang dan menjadi sumber penghasilan kehidupan yang memerlukan keahlian, kemahiran, atau kecakapan yang memenuhi standar mutu atau norma tertentu serta memerlukan pendidikan profesi". Kebijakan kepala madrasah, dengan memberikan supervisi kepada guru untuk mengetahui sejauh mana guru mampu melaksanakan pembelajaran secara berkala, maka dapat dilakukan melalui kegiatan kunjungan kelas untuk mengamati proses pembelajaran secara langsung, terutama dalam pemilihan dan penggunaan metode, media yang digunakan.

Merencanakan suatu program khususnya dalam pengembangan kompetensi profesionali yaitu melakukan analisis dari program- program yang telah dijalankan baik dari segi pelatihan-pelatihan, penataran-penataran. Maka akan diperoleh rancangan yang akan dilaksanakan kedepan baik akan meneruskan program yang telah berjalan, maupun melaksanakan program baru yang sesuai dengan apa yang dibutuhkan dalam pengembangan kompetensi profesional guru tersebut, serta mengalokasikan anggaran khusus dalam pengembangan profesional guru.

Dalam pelaksanaan pengembangan kompetensi profesional guru yakni dengan memberikan fasilitas yang memadai bagi guru seperti media pembelajaran yang lengkap dan media informasi sarana guru mencari informasi dalam peningkatan kemampuanya dalam mengajar dan lainya. Kemudian madrasah melaksanakan pelatihan-pelatihan bagi guru sesuai kebutuhan dalam hal pembelajaran, teknologi informasi, seperti penataran metode pembelajaran, penataran karya tulis ilmiah, sertifikasi profesi/kompetensi, progrm supervisi kepala madrasah, program pemberdayaan MGMP, dan pengembangan yang dilakukan oleh guru sendiri.

Faktor pendukung dalam pengembangan kompetensi profesional guru, pemerintah memberikan fasilitas untuk pengembangan kompetensi profesionalnya dengan menyediakan program workshop dan pelatihanpelatihan, serta memotivasi guru dengan memberikan tunjangan sertifikasi profesi. Kepala madrasah memberikan supervisi dan program pengembangan. Kemudian faktor penghambat yaitu Keterbatasan anggaran sekolah untuk dana program pengembangan kompetensi profesional guru yang mengambat kegiatan pengembangan profesional guru, serta pola pikir guru yang monoton, sehingga ketika mengikuti kegiatan pengembangan, mereka terkadang hanya sebatas menunaikan pekerjaaan saja, tidak ada niatan untuk meningkatan kemampuan profesionalnya.

Dampak dari pengembangan kompetensi profesional guru ialah bagi guru: dalam melakukan tugas dan tanggungjawab sebagai pendidik guru semakin profesional, adanya kedisiplinan yang meningkat, guru termotivasi 
untuk senantiasa mencerdaskan anak didiknya. Bagi peserta didik: ia akan mencintai proses pembelajaran dan memahami arti penting belajar bagi masa depannya, dan akan lebih rajin belajar. Maka dengan menguasai materi pembelajaran peserta didik mampu meningkatkan hasil belajarnya dan memberikan prestasi terbaiknya. Bagi sekolah: madrasah memiliki kurikulum dengan landasan yang kuat, strategi dan metode pembelajaran yang bervariasi, berbagai program yang mengembangkan akademik, bakat, minat dan kreativitas siswa serta tujuan dan standar kompetensi yang tinggi.

\section{DAFTAR PUSTAKA}

Badrudin \& Ruswandi, U. (2010). "Pengembangan Keperibadian Guru". Bandung: CV Insan Mandiri

Danim, S. (2010). Profesionalisasi dan Etika Profesi Guru. Bandung: Alfabeta. Hamalik, O. (2004). Proses Belajar Mengajar. Penerbit : Bumi Aksara, Jakarta. Hamzah B. U. (2007). ProfesiKependidikan: Problema,Solusi,dan Reformasipendidikan di Indonesia. Jakarta: PT. Bumi Aksara.

Hasibuan, M. 1995. Manajemen Sumber Daya Manusia : Dasar dan Kunci Keberhasilan, Jakarta:Toko Gunung Agung.

Moleong, L. (2016). Metodologi Penelitian Kualitatif. Bandung. PT Remaja Rosda Karya.

Mulyasa. (2005). Menjadi Guru Profesional, Menciptakan Pembelajaran Kreatif dan Menyenangkan. Bandung: PT. Remaja Roosdakarya.

Peraturan Menteri PAN dan Reformasi Birokrasi No. 16 Tahun 2009 tentang Jabatan Fungsional Guru dan Angka Kreditnya.

Peraturan Pemerintah Nomor 74 Tahun 2008 tentang Guru(Lembaran Negera RI Tahun 2008 Nomor 194)

Sudarman, M. (2013). Profesi Guru, Dipuji, Dikritis, dan Dicaci. Jakarta: PT Raja Grafindo Persada.

Suparlan. (2008). Guru Sebagai Profesi. Yogyakarta: Hikayat Publishing

Syagala, S. (2011). Kemampuan Profesional Guru dan Tenaga Kependidikan. Bandung:Alfabeta

Undang-Undang Republik Indonesia Nomor 20 Tahun2003 Tentang Sistem Pendidikan Nasional. Bandung: Fokusmedia.

Undang-Undang Republik Indonesia Nomor 14 Tahun 2005 Tentang Guru dan Dosen. Bandung: Fokusmedia.

Wibowo, A. 2013. Manajemen Pendidikan Karakter di Sekolah, Pustaka Pelajar: Yogyakarta. 
Panji Alam Muhammad Ikbal 